\title{
Distribution and photobiology of Symbiodinium types in different light environments for three colour morphs of the coral Madracis pharensis: is there more to it than total irradiance?
}

\author{
P. R. Frade $\cdot$ N. Englebert $\cdot$ J. Faria $\cdot$ P. M. Visser $\cdot$ \\ R. P. M. Bak
}

Received: 29 January 2008 / Accepted: 7 July 2008 / Published online: 11 August 2008

(C) The Author(s) 2008. This article is published with open access at Springerlink.com

\begin{abstract}
The role of symbiont variation in the photobiology of reef corals was addressed by investigating the links among symbiont genetic diversity, function and ecological distribution in a single host species, Madracis pharensis. Symbiont distribution was studied for two depths (10 and $25 \mathrm{~m}$ ), two different light habitats (exposed and shaded) and three host colour morphs (brown, purple and green). Two Symbiodinium genotypes were present, as defined by nuclear internal transcribed spacer 2 ribosomal DNA (ITS2-rDNA) variation. Symbiont distribution was depthand colour morph-dependent. Type B15 occurred predominantly on the deeper reef and in green and purple colonies, while type B7 was present in shallow environments and brown colonies. Different light microhabitats at fixed depths had no effect on symbiont presence. This ecological distribution suggests that symbiont presence is potentially
\end{abstract}

Communicated by Biology Editor Dr. Michael Lesser

P. R. Frade $(\bowtie) \cdot$ J. Faria · R. P. M. Bak

Netherlands Institute for Sea Research (NIOZ), P.O. Box 59,

1790 AB Den Burg, Texel, The Netherlands

e-mail: pfrade@nioz.nl

P. R. Frade · N. Englebert · P. M. Visser · R. P. M. Bak

Aquatic Microbiology, Institute for Biodiversity and Ecosystem Dynamics, University of Amsterdam (UvA), Nieuwe Achtergracht

127, 1018 WS Amsterdam, The Netherlands

P. R. Frade

Caribbean Research and Management of Biodiversity

(CARMABI), Piscaderabaai z/n, P.O. Box 2090, Willemstad,

Curacao, Netherlands Antilles

J. Faria

Department of Animal Biology, Faculty of Sciences,

University of Lisbon (FCUL), Campo Grande - Bloco C2,

1749-016 Lisboa, Portugal driven by light spectral niches. A reciprocal depth transplantation experiment indicated steady symbiont populations under environment change. Functional parameters such as pigment composition, chlorophyll $a$ fluorescence and cell densities were measured for $25 \mathrm{~m}$ and included in multivariate analyses. Most functional variation was explained by two photobiological assemblages that relate to either symbiont identity or light microhabitat, suggesting adaptation and acclimation, respectively. Type B15 occurs with lower cell densities and larger sizes, higher cellular pigment concentrations and higher peridinin to chlorophyll $a$ ratio than type B7. Type $\mathrm{B} 7$ relates to a larger xanthophyll-pool size. These unambiguous differences between symbionts can explain their distributional patterns, with type B15 being potentially more adapted to darker or deeper environments than B7. Symbiont cell size may play a central role in the adaptation of coral holobionts to the deeper reef. The existence of functional differences between B-types shows that the clade classification does not necessarily correspond to functional identity. This study supports the use of ITS2 as an ecological and functionally meaningful marker in Symbiodinium.

Keywords ITS2 - Genetic diversity · Coral-algal symbiosis $\cdot$ Niche partitioning $\cdot$ Functional diversity Zooxanthellae

\section{Introduction}

Tropical coral reefs face worldwide environmental change under a rapidly shifting climate (Hoegh-Guldberg et al. 2007). To a certain extent, their resilience depends on physiological acclimation or adaptive mechanisms at the level of symbiosis between the coral host and the phototrophic 
dinoflagellate endosymbionts (genus Symbiodinium). Host and symbiont constitute the holobiont, whose success depends on the integrated physiological capacity of the symbiotic partners towards the environment (Trench 1993). In the coral reef ecosystem, light is the most important of a broad set of environmental gradients to which coral holobionts respond (Veron 2000). In the last two decades, a great taxonomic diversity has been unveiled to exist within the algal component (reviewed by Coffroth and Santos 2005). The genus Symbiodinium has been divided into several large clades based on nuclear ribosomal DNA (rDNA) analyses (Rowan and Powers 1991). Within these clades, numerous genetically distinct types have been further characterized, using molecular markers such as the less conserved internal transcribed spacer regions (ITS1 and ITS2) of the rDNA (LaJeunesse 2001; van Oppen et al. 2001). This classification closely approximates physiologically and ecologically distinct populations or species (LaJeunesse 2002; Robison and Warner 2006; Warner et al. 2006; Sampayo et al. 2007; Frade et al. 2008). As distinct algal types are adapted to different light regimes, Symbiodinium functional diversity has been hypothesized to play a major role in regulating coral niche occupation, such as host species distribution over reef slopes (Iglesias-Prieto and Trench 1994; Iglesias-Prieto et al. 2004).

Within its genetic constrains, Symbiodinium shows photoacclimation potential, which allows for a certain phenotypic plasticity (Iglesias-Prieto and Trench 1994). Several photoacclimation mechanisms have been reported, including changes in cellular photosynthetic pigment quality and quantity (e.g. Titlyanov 1981). For instance, amounts of chlorophyll-protein complexes are reported to increase as light availability decreases (Iglesias-Prieto and Trench 1997b), contributing to balance photosynthesis. Whenever there is an over-excitation of the photosynthetic system, photoprotective pathways become active to avoid the damaging effects of excess light energy and oxidative stress. These pathways compete with photochemistry for the deactivation of chlorophyll $a$ excited states and lead to heat dissipation (Muller et al. 2001), a phenomenon known as non-photochemical quenching (NPQ). NPQ is known to be at least partially mediated by the xanthophyll-cycle, involving carotenoid pigments that are converted in a matter of minutes from the harvesting form into the protective form, or vice-versa, depending on the environmental conditions (Muller et al. 2001). Measurements of photosystem II (PSII) fluorescence have been largely used to assess differences in such photosynthetic processes, as they are extremely informative regarding processes that affect both the light harvesting antennae and electron transfer chains (Gorbunov et al. 2001; Iglesias-Prieto et al. 2004). These and other functional parameters have also been used to characterize the activity of genetically distinct symbionts
(Warner and Berry-Lowe 2006; Warner et al. 2006; Loram et al. 2007), but completely unambiguous in situ evidence of symbiont functional diversity is still scarce.

In addition to processes determined by the algal component, the importance of host species-specific properties in regulating symbiont activity has been recently emphasized (Frade et al. in press). In fact, there are host-related mechanisms, such as tissue behaviour (Brown et al. 2002), skeletal morphology (Enriquez et al. 2005) and host pigment composition (Schlichter et al. 1994; Salih et al. 2000), which can contribute to modulate photosynthetic response. The presence of fluorescent proteins in the animal component, together with the concentration of symbiont cells, contributes to the colouration of scleractinian corals (Dove et al. 2006; Oswald et al. 2007). Symbionts convey a brown colour to coral surfaces, which may pale or increase depending on cell or photosynthetic pigment densities (Porter et al. 1984). In the animal component, most attention is focussed on the green fluorescent protein (GFP)-like proteins, fluorescent under ultraviolet or visible light and producing the colour patterns of reef-building corals (Dove et al. 2001), such as brilliant greens, reds and blues. The animal pigments are suggested to have either a photoprotective (Salih et al. 2000) or photoenhancing (Schlichter et al. 1994) role. In this later case, pigments are suggested to capture short-wavelength light and re-emit it at suitable wavelengths for photosynthesis. Either way, an alteration of the internal light climate may have an impact on the preference of certain symbiont strains.

Some coral groups have been comprehensively investigated in terms of symbiont diversity, such as the coral genus Madracis Milne Edwards \& Haime 1849. Despite the large depth range covered, ca. 2 to $>100 \mathrm{~m}$ on Caribbean reefs (Wells 1973; Vermeij and Bak 2002), all Madracis species harbour clade B Symbiodinium only (Diekmann et al. 2002). Frade et al. (2008) described three Symbiodinium ITS2 types in the Madracis genus: types B7, B13 and B15 Symbiodinium. That study suggested depth-based ecological function and host-specificity for Symbiodinium ITS2 types in Madracis. However, the mechanisms behind such distribution of symbiont types are unknown. The most common Madracis species, Madracis pharensis, showed depth-related symbiont variation, with the depth-specialist type B15 Symbiodinium replacing the depth-generalist type B7 with increasing depth, while the symbiont assemblage was constant within colonies over colony surface. At a depth of $25 \mathrm{~m}$, the $M$. pharensis colonies are reported to harbour one of two symbiont ITS2 types at an even frequency, thus providing a good opportunity to study the performance of distinct symbiont types living at the same habitat within the tissue of the same host. Furthermore, M. pharensis is known to exhibit colour variation, with diverse colour morphs described in detail for the reefs of 
Curaçao (Vermeij et al. 2002; Sheppard et al. 2007). The role of these host colour morphs in controlling symbiont diversity has not been investigated.

Although much data has been gathered on symbiont diversity and distribution in scleractinian corals, the in situ functional role of specific Symbiodinium types has only been briefly studied (Warner and Berry-Lowe 2006; Warner et al. 2006; Frade et al. in press). In addition, the low number of parameters studied and the univariate statistical approaches usually applied fail to cope with the need of searching for overall patterns. Additional work on holobiont photobiology is necessary to better understand the role of symbiont intra-cladal variation in these symbioses. In the present study, the links among symbiont function, genetic identity and ecological distribution are investigated by sampling algae from a single host species, M. pharensis, in distinct light habitats and exhibiting different colour morphs. The main objective is to understand the mechanisms controlling symbiont photobiology and distribution in tropical reef-building corals.

\section{Materials and methods}

Study site

Fieldwork was conducted in August-September 2006 at the Buoy One reef location (e.g. Bak 1977; Vermeij et al. 2007), Curaçao, southern Caribbean (at ca. $12^{\circ} 07^{\prime} 31.00^{\prime \prime} \mathrm{N}$, $68^{\circ} 58^{\prime} 27.00^{\prime \prime}$ W. Fig. 1). Site descriptors, such as the depthmediated light attenuation, light spectral distribution and seawater temperature, have been previously characterized (Frade et al. 2008).

Sampling approach

All research was conducted on the coral species Madracis pharensis (Heller 1868), a depth generalist distributed from 5 to $>60 \mathrm{~m}$ (Vermeij and Bak 2003; Frade et al. 2008). The study involves two separate approaches, related with symbiont distribution and symbiont function, respectively. For the first part of the study, the only biological variable assessed is Symbiodinium genetic identity. Factors controlling $M$. pharensis symbiont genetic diversity and distribution are addressed for two depths (10 and $25 \mathrm{~m})$, two different microhabitat categories (in terms of exposition to light: exposed or shaded) and three host colour morph (brown, purple or green, based on the overall colour of coenosarc; see Fig. 2). Additionally, at $10 \mathrm{~m}$, M. pharensis colonies extending from shaded (crevices) into exposed positions were also sampled for these two distinct intracolony microhabitats. Furthermore, to investigate whether M. pharensis symbiont composition is stable over time

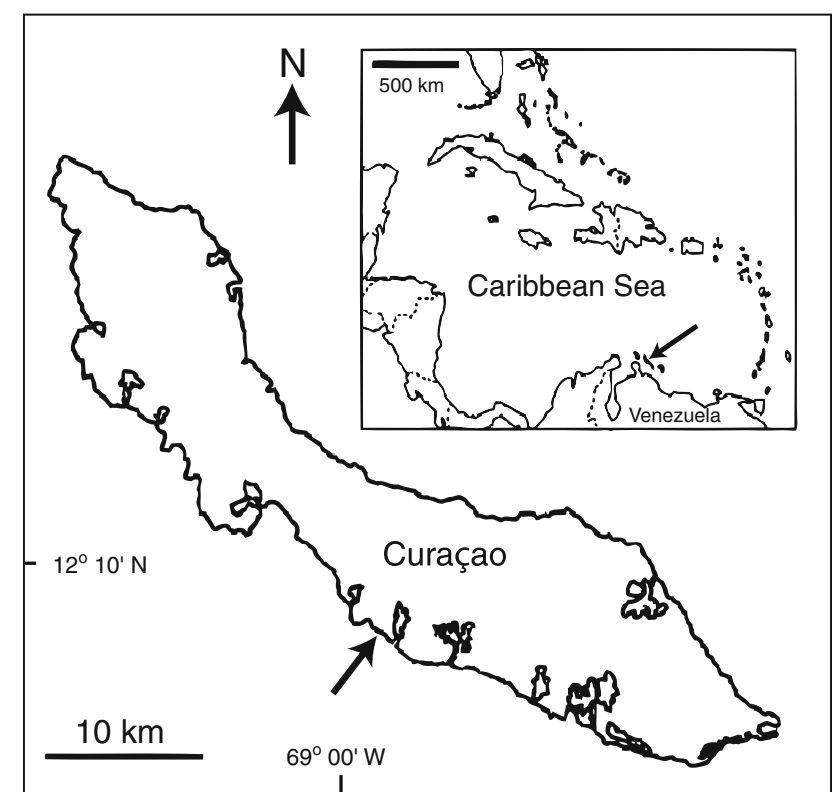

Fig. 1 Curaçao and the study site Buoy One (arrows)

under environmental changes, a set of reciprocal transplantations from 10 to $25 \mathrm{~m}$ were performed. Nine exposed colonies were collected at each depth, moved and fixed to racks placed at similar exposed positions at the new depths. These were sampled before and one month after transplantation.

The second part of the study, addressing the function of the symbiotic association, consisted of measuring and analyzing several in situ photobiological parameters, such as photosynthetic activity, symbiont cell density or size. These measurements were taken on most of the colonies that were sampled for symbiont genetic characterization at $25 \mathrm{~m}$ of depth.

\section{Light microhabitat}

In order to verify the objectivity of the light microhabitat categorization at 10 and $25 \mathrm{~m}$, vertical incident irradiance (horizontal, in the case of colonies growing inside crevices at $10 \mathrm{~m}$ ) was measured at noon for part of the sampled colonies using a photosynthetic active radiation (PAR, 400$700 \mathrm{~nm}$ ) cosine-corrected LI-192SA light sensor (Li-Cor). Taken under conditions of minor cloud cover, the measurements were standardized to the irradiance value measured in the open water column at the same occasion and homologous depth, to correct for meteorological bias (Vermeij and Bak 2002).

Fluorescence measurements

Fluorescence measurements were taken in situ, at solar noon $( \pm 30 \mathrm{~min})$ on days with low cloud cover, using 
Fig. 2 Madracis pharensis colour morphs included in the study: (a, b) brown morph; $(\mathbf{c}, \mathbf{d})$ purple morph; (e, f) green morph. Note that Vermeij et al. (2002) identified 25 colour morphs based on colour variation of several polyp features. The present classification, which is less detailed, is based on visual observations of the overall colour of the coenosarc. Present green morph corresponds to green polyp colour morphs in Vermeij et al. (2002); present brown morph corresponds to brown polyp morphs and part of the grey polyp morphs in Vermeij et al. (2002) (see Fig. 2a for a brown colony with grey polyps); present purple colour morph corresponds to part of the grey polyp morphs in Vermeij et al. (2002) (see Fig. 2c for a purple colony with grey polyps)
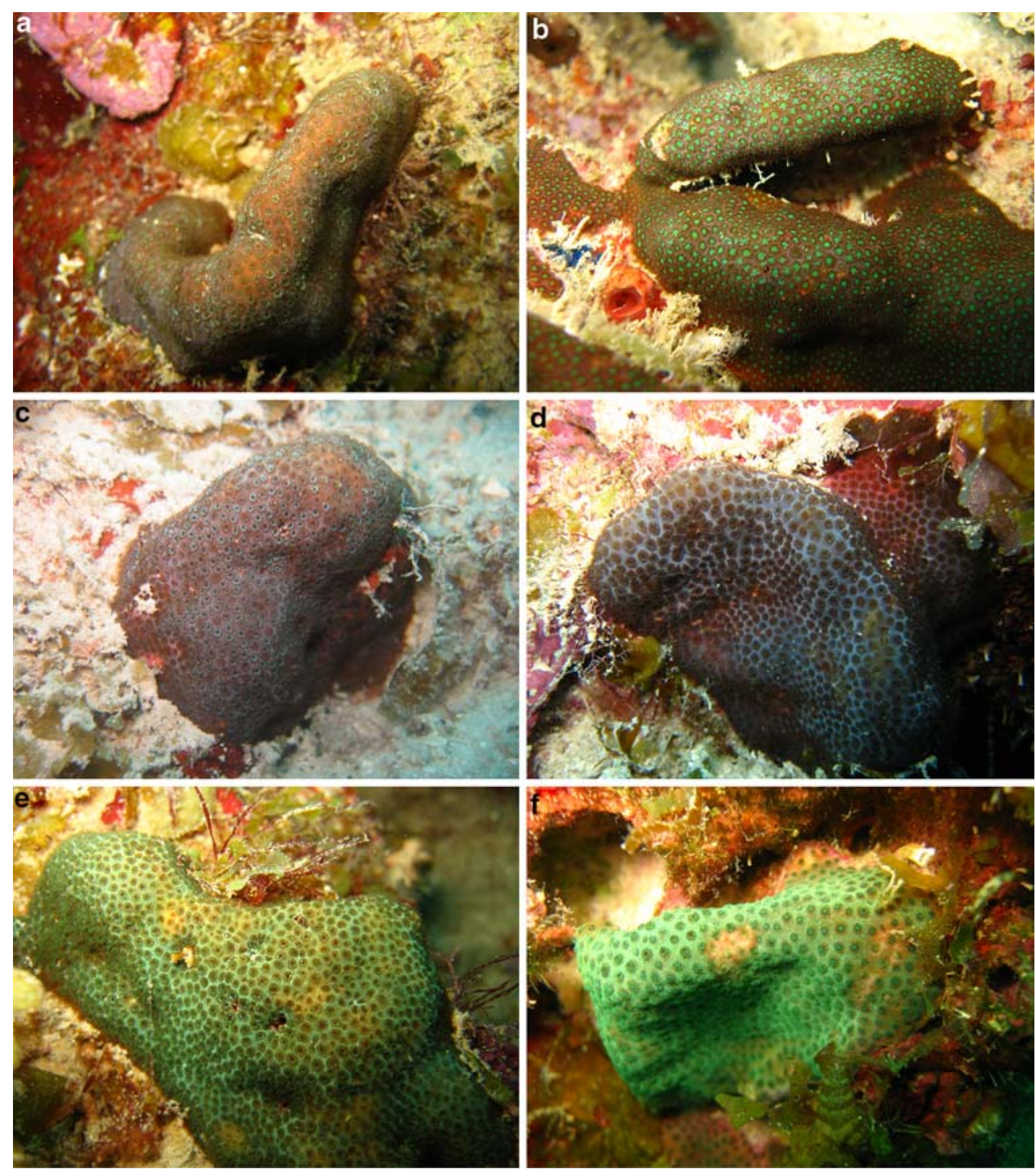

underwater pulse amplitude modulated fluorometry (Diving-PAM, Walz). Each colony was sampled contiguously to the area further used for the other analyses. Distance between PAM fibreoptics and sample was kept at $10 \mathrm{~mm}$. Effective quantum yield (Y) was measured during "rapid light curves", preceded by 1 min dark acclimation to completely relax photochemical quenching (Iglesias-Prieto et al. 2004). Photosynthesis-irradiance (PE) curves were built using relative ETR (electron transfer rate) as photosynthetic rate estimator: $\mathrm{ETR}=\mathrm{Y} \times \mathrm{PAR} \times 0.5 \quad$ (Beer et al. 1998). The following parameters were derived from the PE curves (Iglesias-Prieto and Trench 1994): alpha, or the photosynthetic efficiency at sub-saturating irradiances, calculated as the linear regression of the light-limited photosynthetic rates (including the lowest three PAR levels); ETRmax, or the maximum photosynthetic rate, calculated as the average of the two highest photosynthetic rate points; and $\mathrm{E}_{\mathrm{k}}$, or the saturation irradiance parameter, calculated as the quotient of ETRmax per alpha.

\section{Coral collection and processing}

All sample collection was done by means of SCUBA. Care was taken to sample the horizontal top surface (except in the case of cryptic habitats at $10 \mathrm{~m}$ ) of adult, healthy, fully pigmented colonies. Coral fragments were collected with hammer and chisel and placed in seawater-filled plastic bags that were kept in dark and immediately transported at seawater temperature to the laboratory of the Caribbean Research and Management of Biodiversity (CARMABI) station. Coral tissue was completely removed from a ca. $1-4 \mathrm{~cm}^{2}$ fragment sub-sample using a waterpik jet of $0.2 \mu \mathrm{m}$ filtered seawater. Sub-samples of the homogenized blastate were further processed to be used in pigment analyses 
(loaded on 0.45 - $\mu$ m cellulose acetate membrane filters that were frozen in liquid nitrogen and kept at $-80^{\circ} \mathrm{C}$ after being freeze-dried), symbiont cell density (sub-sample concentrated, fixed in $0.5 \%$ glutaraldehyde, frozen in liquid nitrogen and kept at $-80^{\circ} \mathrm{C}$ ) and size determinations (photographs of fresh symbiont isolates taken under the microscope). Total surface area of the waterpiked fragments was estimated using the aluminium foil method (Marsh 1970) and was used for further standardizations.

\section{Genetic analyses}

A ca. $4 \mathrm{~cm}^{2}$ sub-sample of each coral fragment was used for the genetic characterization of the Symbiodinium population present. Coral tissue was removed with a sterile scalpel and preserved in $95 \%$ ethanol at $-20^{\circ} \mathrm{C}$. DNA was precipitated by centrifugation and ethanol was washed out before further DNA extraction (UltraClean Soil DNA kit by MoBio). Polymerase chain reaction (PCR) and denaturing gradient gel electrophoresis (DGGE) fingerprinting of the Symbiodinium ITS2-rDNA region were coupled for each sample (LaJeunesse 2002; LaJeunesse et al. 2003; Warner et al. 2006; Sampayo et al. 2007). The sensitivity of the PCR-DGGE technique as a measure of Symbiodinium diversity has recently been scrutinized (Apprill and Gates 2007; Thornhill et al. 2007). For detailed information on the PCR and DGGE protocols applied and band profile identification, see Frade et al. (2008).

\section{Pigment analyses}

Photosynthetic pigment composition was analyzed in a Millipore-Waters high-performance liquid chromatography (HPLC) system, after ice-cold extraction by ultra-sonification (solvent: $95 \%$ methanol, 2\% ammonium acetate). Pigment concentrations were calculated after integration of the 436nm-absorbance peak areas (Waters Empower 2 software) by linear extrapolation using conversion factors determined by running Sigma pigment standards in the same HPLC system (except for dinoxanthin, for which the conversion factor was estimated by assuming a similar molar extinction coefficient as diadinoxanthin and correcting it according to the difference in molecular weight). The following photosynthetic pigments were abundant in all samples: chlorophyll $a(\operatorname{chl} a)$, chlorophyll $c_{2}\left(\mathrm{chl} c_{2}\right)$ and the carotenoids peridinin, dinoxanthin, diadinoxanthin and $\beta$ - $\beta$ carotene. Residual amounts $(<1 \% \operatorname{chl} a)$ of other pigments such as diatoxanthin, chlorophyll $c_{1}$ or chlorophyll $b$ were occasionally detected. Because samples were kept in the dark for 1 to $2 \mathrm{~h}$ from collection to fixation, data on individual xanthophyll levels are not reliable (diatoxanthin converted to diadinoxanthin by epoxidation, Muller et al. 2001) and only the value for the total pool (diadinoxanthin plus diatoxanthin) was included in the analyses.
Symbiont cell density and size

Symbiont cell densities were determined by flowcytometry (Epics XL-MCL Beckman Coulter). Using the photographs of fresh isolates, the maximum cell diameter was digitally determined (Image J software) for a minimum of 100 single symbiont cells per sample.

\section{Statistics}

Incident irradiances were ln-transformed and analysed separately for 10 and $25 \mathrm{~m}$ by bivariate linear regression to test whether the different light microhabitat categories attributed during the dives (exposed and shaded) relate to statistically distinct light regimes.

Logistic regression (binomial distribution for the error terms and logit link function) was applied to model the distribution (presence/absence) of each Symbiodinium ITS2type found (Frade et al. 2008). The null hypothesis states that the presence of a symbiont type is not related to any of the main factors. These included host colour morph and colony light microhabitat or transplantation effect, depending on the dataset to which the regression was applied (see Sampling Approach paragraph). Samples containing missing values were removed prior to the analyses. A model selection tool was used, when applicable, to identify the variables that accounted for a significant amount of the variation in the response variable (Zuur et al. 2007). The adequate model was reached when no variable could be deleted from the model without causing a statistically significant change in deviance ( $\chi^{2}$ distributed). Interactions between main factors were also tested.

In order to identify general trends in the photobiological response, all functional parameters were included in a principal component analysis (PCA). Samples containing missing data were excluded. Log-transformations were applied when necessary to improve linearity and reduce outlier effect. Data in the form of percentages (pigment ratios) were instead arcsin transformed. All variables were normalized before PCA. Three main principal components (PCs) were retained. The resulting loadings were used to compute new PCs scores for each sample. The three PCs were used as response variables in multiple linear regression models (ANOVA). These test whether there is a significant effect of the explanatory factors on the photobiology of the symbiotic association. Since preliminary analyses using the variance inflation factor (VIF) showed no relevant collinearity between the three explanatory variables (VIF $<5$; Zuur et al. 2007), all of them (symbiont type, light microhabitat and host colour morph) were tested in the multiple regressions. All statistical tests applied at a significance level of 0.05 and p-values adjusted according to Bonferroni correction. Modelling was performed with the software Brodgar 
(version 2.5.6), linked to the statistics package $\mathrm{R}$ (version 2.6.0)

\section{Results}

\section{Light microhabitat}

Ln-transformed colony incident irradiances differed significantly between the microhabitat categories for both $10 \mathrm{~m}$ $\left(F_{1,18}=444.57, P<0.05\right)$ and $25 \mathrm{~m}\left(F_{1,29}=6.7041, P<0.05\right)$. At $10 \mathrm{~m}$, colonies in shaded (cryptic) habitats received, on average, $5 \%$ of irradiance measured for exposed positions $\left(33 \pm 18\right.$ and $619 \pm 106 \mu \mathrm{mol}$ photons $\mathrm{m}^{-2} \mathrm{~s}^{-1}$, respectively). At $25 \mathrm{~m}$, average ( $\pm \mathrm{SD}$ ) irradiances were $183 \pm 38$ and $145 \pm 47 \mu \mathrm{mol}$ photons $\mathrm{m}^{-2} \mathrm{~s}^{-1}$, for exposed and shaded colonies, respectively. This difference, although significant, does not represent a broad light gradient, with shaded colonies receiving on average $79 \%$ of incident irradiance in exposed microhabitats.

\section{Symbiont diversity and distribution}

For the different experimental sets, a total of 139 genetic samples were included in the PCR-DGGE protocol, producing clear band fingerprinting profiles that were compared with the profiles in Frade et al. (2008). Generated sequences corresponded to two distinct ITS2 signatures: Symbiodinium B7 and B15 types, identical to NCBI GenBank accession numbers EF450566-611 and EF450612626 , respectively. In the present study, these two distinct types never co-occurred at the level of detection of the PCR-DGGE protocol applied (Frade et al. 2008). The experiment on reef topography-based symbiont variation at 10-m depth showed no variation in ITS2 type present: all M. pharensis colonies harboured B7 Symbiodinium, irrespective of being from shaded $(n=16)$ or from exposed positions $(n=25)$. Large colonies extending from shaded (crevices) into exposed positions $(n=10)$ harboured type B7 for both fractions sampled. Thus, there was no effect of light microhabitat (between or within colonies) on symbiont diversity. All colonies from 10-m depth were brown. In cryptic positions, however, they exhibited a darker brown colouration (likely caused by higher symbiont pigment densities, Frade et al. in press). At $25 \mathrm{~m}(n=46)$, approximately $59 \%$ of the sampled colonies harboured type B15, while the other $41 \%$ hosted the B7 type (Fig. 3). The presence of these types at $25 \mathrm{~m}$ is significantly related to host morph colour $\left(\chi^{2}=24.866\right.$, df $\left.=2, n=46, P<0.05\right)$, but, as at $10 \mathrm{~m}$, is not related to light microhabitat. Overall, brown colonies showed a majority of type B7 (80\% of colonies), while purple and green ones harboured mostly the B15 type ( $80 \%$ and $94 \%$, respectively). The statistical significance of

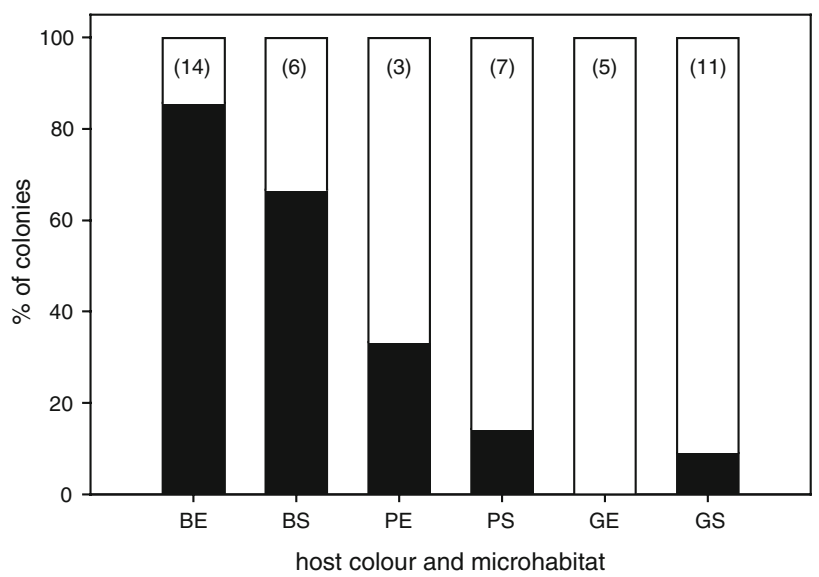

Fig. 3 Madracis pharensis symbiont ITS2-type composition at 25-m depth, per host colour morph (B, brown; P, purple; G, green) and light microhabitat (E, exposed; $S$, shaded). Bars represent percentage of colonies containing a distinct ITS2-type (black - B7, white - B15). Number of colonies indicated between brackets

colour morph on symbiont diversity was again verified after removal of three potential outliers $\left(\chi^{2}=39.749\right.$, df $=2$, $n=43, P<0.05)$.

Besides their variation in overall coenosarc colour (brown, purple or green), all colonies included in this study exhibited some form of colour variation in polyp features such as mouths and tentacles (Fig. 2 and Vermeij et al. 2002). This variation included combinations such as green, yellow or red mouths, green or cyan tentacle tips, green or cyan mouth fields or grey punctuations throughout the tentacles. There was no evidence of a relation between these colour combinations and symbiont diversity at any of the sampled depths or within any of the three colour morphs.

\section{Transplantations}

All colonies included in downward transplantations $(n=9)$, i.e. originating from 10-m depth, harboured type B7. One month later, all colony fragments appeared healthily pigmented and the collected samples showed no change in symbiont type. Of the nine colonies included in the upward transplantations, four harboured type B15 and five harboured type B7. All colonies suffered from excessive light stress, as suggested by observations of extensive bleaching. Table 1 summarizes the results for the upward transplantation. Four of these colonies (three originally harbouring B7) had no living tissue left after one month. The five living (but bleached) colonies experienced no detectable (or significant) change in symbiont type, irrespective of the original associated symbiont or colour morph. However, there appears to be a slight tendency for a higher survival rate of brown morphs and colonies harbouring symbiont type B15. Due to low sample size, no statistical tools were applied to test the significance of such tendencies. 
Table 1 Survival of transplanted Madracis pharensis colonies (\% of original colonies alive 1 month after upward transplantation from 25 to $10 \mathrm{~m}$ ) for distinct Symbiodinium type and host colour morph combinations

\begin{tabular}{lrrr}
\hline & \multicolumn{1}{l}{ B7 } & \multicolumn{1}{l}{ B15 } & \multicolumn{1}{l}{ Total } \\
\hline Brown & $67 \%(3)$ & $100 \%(1)$ & $75 \%(4)$ \\
Purple & $0 \%(2)$ & $100 \%(1)$ & $33 \%(3)$ \\
Green & $-(0)$ & $50 \%(2)$ & $50 \%(2)$ \\
Total & $40 \%(5)$ & $75 \%(4)$ & $56 \%(9)$ \\
\hline
\end{tabular}

Number of colonies indicated between brackets

\section{Symbiont photobiology}

Table 2 shows overall variation and mean values for each symbiont type and light microhabitat combination (for a total of 41 colonies) for each of the 17 variables representing distinct photobiological processes, some of which are alternative normalizations of the same data. Symbiont cell densities showed high overall variation, ranging between 1.0 and 2.5 million cells $\mathrm{cm}^{-2}$ of coral surface. Cell size varied from 8.5 to $10.7 \mu \mathrm{m}$ in diameter. Amounts of chla per coral surface area and per symbiont cell ranged on a two-fold interval, between 9.9 and $19.3 \mu \mathrm{g} \mathrm{cm}^{-2}$ and 6.2 and $13.0 \mathrm{pg} \mathrm{cell}^{-1}$, respectively. Because variation in absolute pigment contents was highly correlated to chla amounts (data not shown), each pigment was normalized to chl $a$ prior to further analyses. Photosynthetic pigment ratios to $\operatorname{chl} a$ were relatively stable. Fluorescence-determined photosynthetic parameters showed relatively higher variation, which nevertheless did not exceed a three-fold range.

The results of the PCA $(n=39$, after removing samples missing data in the response variables) for the 17 functional parameters listed in Table 2 showed that the first three PCs accounted for a total of $73 \%$ of the variation (Table 3 ). Each PC represents a distinct set of original variables (see bold values in Table 3), which are likely to reflect a common underlying photoresponse mechanism.

The significance of symbiont ITS2-type, host colour morph and light microhabitat was tested for each PC ( $n=35$, after removing samples missing data in the explanatory factors). PC1 (accounting for $36 \%$ of variation) is significantly related with symbiont type $\left(F_{1,33}=80.771\right.$, $P<0.05)$, with PC1 scores higher for type B15 than type B7. Host microhabitat and colour morph had no significant effect on PC1. PC2 (28\% of variation) scores did not vary significantly between symbiont types or colour morphs, but were slightly higher in exposed than shaded microhabitats $\left(F_{1,33}=5.3134, P=0.08\right)$. Finally, PC3 (explaining only $9 \%$ of the variation) was not significantly related with any of the explanatory factors tested. Repeating the multiple regression analyses after removing four outliers $(n=35)$ yielded very similar PCA results (accounting for $75 \%$ of variation) and confirmed the mentioned statistical significances (for $n=31$ ), including the microhabitat effect on PC2 $\left(F_{1,29}=7.1623, P<0.05\right)$.

The original data corresponding to these statistically significant comparisons are expressed in Figs. 4 and 5 for

Table 2 Photobiological functional variables for Madracis pharensis at $25 \mathrm{~m}$ for each Symbiodinium type and light microhabitat combination (average $\pm \mathrm{SD}$ )

\begin{tabular}{|c|c|c|c|c|c|}
\hline Variable & Overall range & B7, exposed & B7, shaded & B15, exposed & B15, shaded \\
\hline Cell density $\left(\times 10^{6} \mathrm{~cm}^{-2}\right)$ & $1.0-2.5(40)$ & $2.0 \pm 0.6(10)$ & $1.8 \pm 0.4(4)$ & $1.3 \pm 0.2(8)$ & $1.4 \pm 0.3(14)$ \\
\hline Cell size $(\mu \mathrm{m})$ & $8.5-10.7(40)$ & $8.7 \pm 0.2(10)$ & $9.2 \pm 1.0(4)$ & $10.4 \pm 0.5(7)$ & $10.4 \pm 0.3(15)$ \\
\hline $\operatorname{chl} a \operatorname{area}^{-1}\left(\mu \mathrm{g} \mathrm{cm}^{-2}\right)$ & $9.9-19.3(39)$ & $14.6 \pm 4.7(10)$ & $13.8 \pm 1.8(4)$ & $13.5 \pm 1.8(7)$ & $16.0 \pm 2.3(14)$ \\
\hline chl $a$ cell $^{-1}\left(\mathrm{pg} \mathrm{cell}^{-1}\right)$ & $6.2-13.0(39)$ & $7.2 \pm 1.2(10)$ & $7.7 \pm 1.2(4)$ & $10.5 \pm 1.5(7)$ & $11.8 \pm 1.8(14)$ \\
\hline 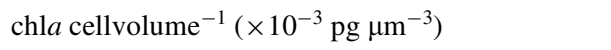 & $15.5-24.5(39)$ & $20.7 \pm 2.5(10)$ & $19.2 \pm 4.8(4)$ & $17.8 \pm 1.5(7)$ & $20.0 \pm 2.8(14)$ \\
\hline $\operatorname{chl} c_{2} \operatorname{chl} a^{-1}$ & $0.23-0.27(41)$ & $0.27 \pm 0.01(10)$ & $0.26 \pm 0.01(4)$ & $0.24 \pm 0.01(8)$ & $0.24 \pm 0.01(15)$ \\
\hline Peridinin $\operatorname{chl} a^{-1}$ & $0.69-0.82(41)$ & $0.72 \pm 0.02(10)$ & $0.73 \pm 0.04$ & $0.78 \pm 0.02(8)$ & $0.79 \pm 0.02(15)$ \\
\hline Dinoxanthin $\operatorname{chl} a^{-1}\left(\times 10^{-1}\right)$ & $0.44-0.58(41)$ & $0.53 \pm 0.04(10)$ & $0.54 \pm 0.06$ & $0.50 \pm 0.05(8)$ & $0.48 \pm 0.04(15)$ \\
\hline$\beta$ - $\beta$-Carotene $\operatorname{chl} a^{-1}\left(\times 10^{-1}\right)$ & $0.15-0.23(41)$ & $0.19 \pm 0.03(10)$ & $0.20 \pm 0.02(4)$ & $0.20 \pm 0.03(8)$ & $0.21 \pm 0.02(15)$ \\
\hline Xanthophyll-pool chl $a^{-1}\left(\times 10^{-1}\right)$ & $1.45-1.70(41)$ & $1.64 \pm 0.05(10)$ & $1.61 \pm 0.03(4)$ & $1.59 \pm 0.09(8)$ & $1.55 \pm 0.07(15)$ \\
\hline ETRmax $\left(\mu \mathrm{mol}\right.$ electrons $\left.\mathrm{m}^{-2} \mathrm{~s}^{-1}\right)$ & $30.4-56.0(41)$ & $48.6 \pm 7.4(10)$ & $38.5 \pm 12.2(4)$ & $43.6 \pm 6.5(8)$ & $40.2 \pm 6.2(15)$ \\
\hline Alpha & $0.25-0.31(41)$ & $0.28 \pm 0.01(10)$ & $0.29 \pm 0.02(4)$ & $0.27 \pm 0.03(8)$ & $0.29 \pm 0.02(15)$ \\
\hline$E_{k}\left(\mu \mathrm{mol}\right.$ photons $\left.\mathrm{m}^{-2} \mathrm{~s}^{-1}\right)$ & $107-191(41)$ & $172 \pm 25(10)$ & $132 \pm 35(4)$ & $163 \pm 29(8)$ & $139 \pm 23(15)$ \\
\hline ETRmax cell $^{-1}\left(\times 10^{-6} \mu \mathrm{mol}\right.$ electrons cell $\left.{ }^{-1} \mathrm{~h}^{-1}\right)$ & $5.6-15.5(40)$ & $9.7 \pm 5.0(10)$ & $7.7 \pm 2.2(4)$ & $12.7 \pm 2.5(8)$ & $10.8 \pm 3.0(14)$ \\
\hline ETRmax chl $a^{-1}\left(\mu \mathrm{mol}\right.$ electrons $\left.\mathrm{mg}^{-1} \operatorname{chl} a \mathrm{~s}^{-1}\right)$ & $0.17-0.45(39)$ & $0.37 \pm 0.14(10)$ & $0.28 \pm 0.08(4)$ & $0.33 \pm 0.08(7)$ & $0.26 \pm 0.07(14)$ \\
\hline Alpha cell ${ }^{-1}$ & $0.11-0.28(40)$ & $0.16 \pm 0.06(10)$ & $0.16 \pm 0.04$ & $0.22 \pm 0.04(8)$ & $0.22 \pm 0.04(14)$ \\
\hline Alpha chl $a^{-1}\left(\times 10^{-1}\right)$ & $0.15-0.29(39)$ & $0.21 \pm 0.07(10)$ & $0.21 \pm 0.03$ & $0.21 \pm 0.03(7)$ & $0.18 \pm 0.02(14)$ \\
\hline
\end{tabular}

Overall range is given by 5 th and 95 th percentile. Number of colonies indicated between brackets 
Table 3 PC loadings for each original variable and cumulative variation accounted for by each component for the Madracis pharensis photobiological dataset at $25 \mathrm{~m}$

\begin{tabular}{|c|c|c|c|}
\hline Variable & $\mathrm{PC} 1$ & $\mathrm{PC} 2$ & PC3 \\
\hline Cell density & -0.34 & -0.22 & 0.08 \\
\hline Cell size & 0.38 & -0.01 & -0.04 \\
\hline $\operatorname{chl} a \operatorname{area}^{-1}$ & -0.02 & -0.39 & $\mathbf{0 . 3 3}$ \\
\hline chl $a$ cell $^{-1}$ & 0.38 & -0.06 & 0.18 \\
\hline chl $a$ cellvolume ${ }^{-1}$ & -0.04 & -0.10 & 0.41 \\
\hline $\operatorname{chl} c_{2} \operatorname{chl} a^{-1}$ & -0.36 & -0.01 & -0.06 \\
\hline Peridinin $\operatorname{chl} a^{-1}$ & 0.31 & -0.12 & 0.11 \\
\hline Dinoxanthin chl $a^{-1}$ & -0.27 & 0.15 & -0.15 \\
\hline$\beta-\beta$-Carotene chl $a^{-1}$ & 0.15 & -0.13 & 0.04 \\
\hline Xanthophyll-pool chl $a^{-1}$ & -0.29 & 0.11 & -0.01 \\
\hline ETRmax & -0.12 & 0.30 & 0.47 \\
\hline Alpha & -0.01 & -0.08 & -0.08 \\
\hline$E_{k}$ & -0.11 & 0.33 & 0.47 \\
\hline ETRmax cell $^{-1}$ & 0.23 & 0.36 & 0.19 \\
\hline ETRmax $\operatorname{chl} a^{-1}$ & -0.05 & 0.45 & 0.07 \\
\hline Alpha cell ${ }^{-1}$ & 0.34 & 0.20 & -0.10 \\
\hline Alpha $\operatorname{chl} a^{-1}$ & 0.02 & 0.38 & -0.37 \\
\hline Cumulative variance $(\%)$ & 35.6 & 63.9 & 73.3 \\
\hline
\end{tabular}

Bold values highlight strong correlations [loading $>0.2$ ] between original variables and PCs

PC1 and PC2, respectively. These figures show, for each original variable that strongly correlates to each respective PC (Table 3), the average value per category of the significant explanatory factor. From PC1 (Fig. 4), one learns that symbiont type B7 has significantly higher densities but lower cell size or cellular chla contents than type B15. There are also differences in terms of ratios of accessory pigments to chl $a$ (for chl $c_{2}$, peridinin, dinoxanthin and xanthophyll pool level; see also Table 2). In addition, differences in photosynthetic rates per cell, both at saturating and sub-saturating irradiances, are most likely caused by the difference in cell numbers. PC2 shows (Fig. 5) statistically significant differences between host light microhabitats in photosynthetic rate-related variables, such as ETRmax or $\mathrm{E}_{\mathrm{k}}$, higher in exposed than shaded habitats. Amounts of chl $a$ per area and cell densities also differ between habitats. PC3 represents variables that already strongly load on one of the first two PCs (Table 3), and in addition to accounting only for a minor part of the variation, $\mathrm{PC} 3$ does not relate to any of the explanatory factors, the reason why it is further omitted.

\section{Discussion}

Symbiont diversity in $M$. pharensis is constant across different light microhabitats at a fixed depth, while being highly dependent on host colour morph. On the functional level, the variation involved in the several parameters measured could be attributed to two distinct photobiology assemblages that are under the effect of either symbiont identity or light microhabitat. The following paragraphs address the role of photoadaptation and acclimation on the response of $M$. pharensis coral-symbiont associations and their respective distribution patterns.

Symbiont adaptation: functional differences?

For the same study location, Frade et al. (2008) showed $M$. pharensis symbiont diversity to be depth-related albeit invariable at the intra-colony scale, with the depth-specialist type B15 Symbiodinium replacing the depth-generalist type B7 with depth. The present study confirms this depthrelated symbiont variation, with a higher occurrence of type B15 in deep environments, $25 \mathrm{~m}$, relative to shallow ones, $10 \mathrm{~m}$. Furthermore, there are evident functional differences that can help explain the observed distributional patterns of these symbiont types. Type B15 occurs at significantly lower densities, shows larger cells, higher chl $a$ amounts per cell (as well as for all other pigments) and a higher peridinin to chl $a$ ratio as compared to $\mathrm{B} 7$ type. Type $\mathrm{B} 15$ also shows higher cellular photosynthetic efficiencies at sub-saturating light levels. Combined together, these results suggest that type B15 is a more shade-adapted organism than type B7. For instance, it is likely that a higher amount of peridinin in type B15 could provide a competitive advantage under reduced irradiance, as this carotenoid has a maximum absorbance in the $500-560 \mathrm{~nm}$ range, the blue-green region, thus broadening the absorption spectrum of the phototrophic component under conditions of light-limitation. On the other hand, type B7 relates to a larger dinoxanthin to chla ratio and larger xanthophyll-pool size, suggesting that it is probably more competent in releasing excess of energy and more adapted to high-light habitats. It is possible that the differences in pigments and photosynthetic activity between the two symbiont types are the end result of acclimation responses to symbiont cell size- and density-dependent light availability or self-shading. In this case, the genetic constrained, adaptive, trait between distinct symbiont types would be cell size (as in LaJeunesse et al. 2005), and cell density is a consequence of space availability (Jones and Yellowlees 1997). This is supported by the recurrent difference in cell size between the two symbiont genotypes, type B7 occurring with smaller cells than type B15. Whether occurring at lower densities (because of having larger cell size) is a strategy that can be advantageous to a symbiont at greater depths remains an open question. Hypothetically, this strategy could allow the holobiont to minimize respiration loss by the endosymbionts, offering a maximization of energy balance. Cell 

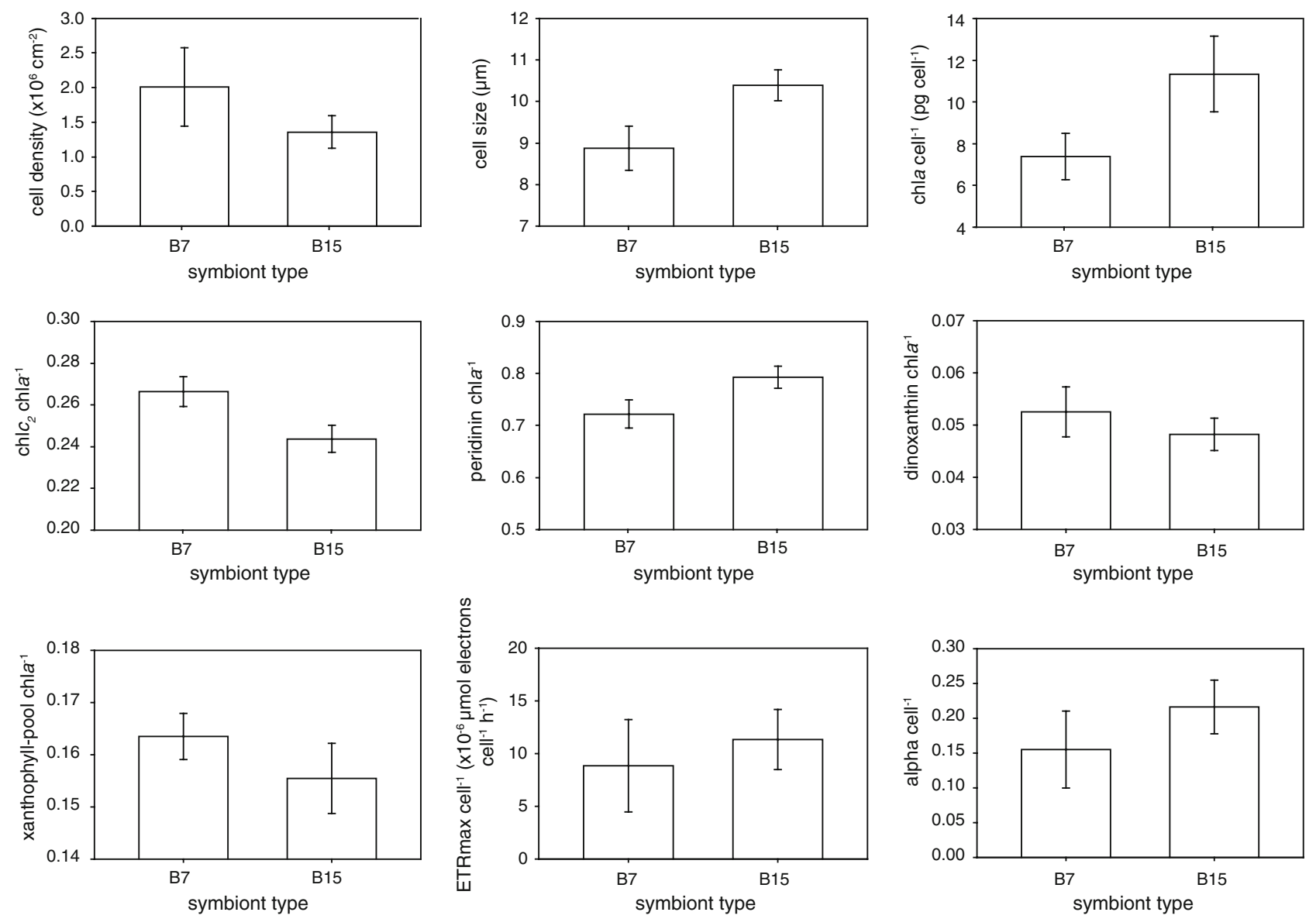

Fig. 4 Symbiont type differences (average $\pm \mathrm{SD}$ ) in Madracis pharensis at $25 \mathrm{~m}$ for the original variables that are highly correlated to (represented in) PC1. Note that statistical significances throughout the text are based on the overall variation of the component representing these variables and not on individual comparisons

Although some of these parameters also constitute an axis for symbiont type distinction (i.e. also load on PC1, see Table 3), these photosynthetic differences appear to go beyond the genetic distinction between types and are evidence for the general acclimation capacity of Symbiodinium. When facing small differences in light environment, the photosynthetic apparatus will compensate and adjust itself, irrespective of symbiont type. Overall, it is tempting to suggest that by using distinct settings (here, described as functional differences), both symbiont types studied end up achieving a similar photosynthetic response due to broad acclimation plasticity. Given the fact that such similar responses may depend on different energetic costs, it can be expected that there is a differential selective pressure over the symbionts, leading to distributional differences.

Symbiont distribution: is there more to it than total irradiance?

Frade et al. (2008) mention attenuation of light with depth as the most likely cause for B7 to B15 symbiont change 

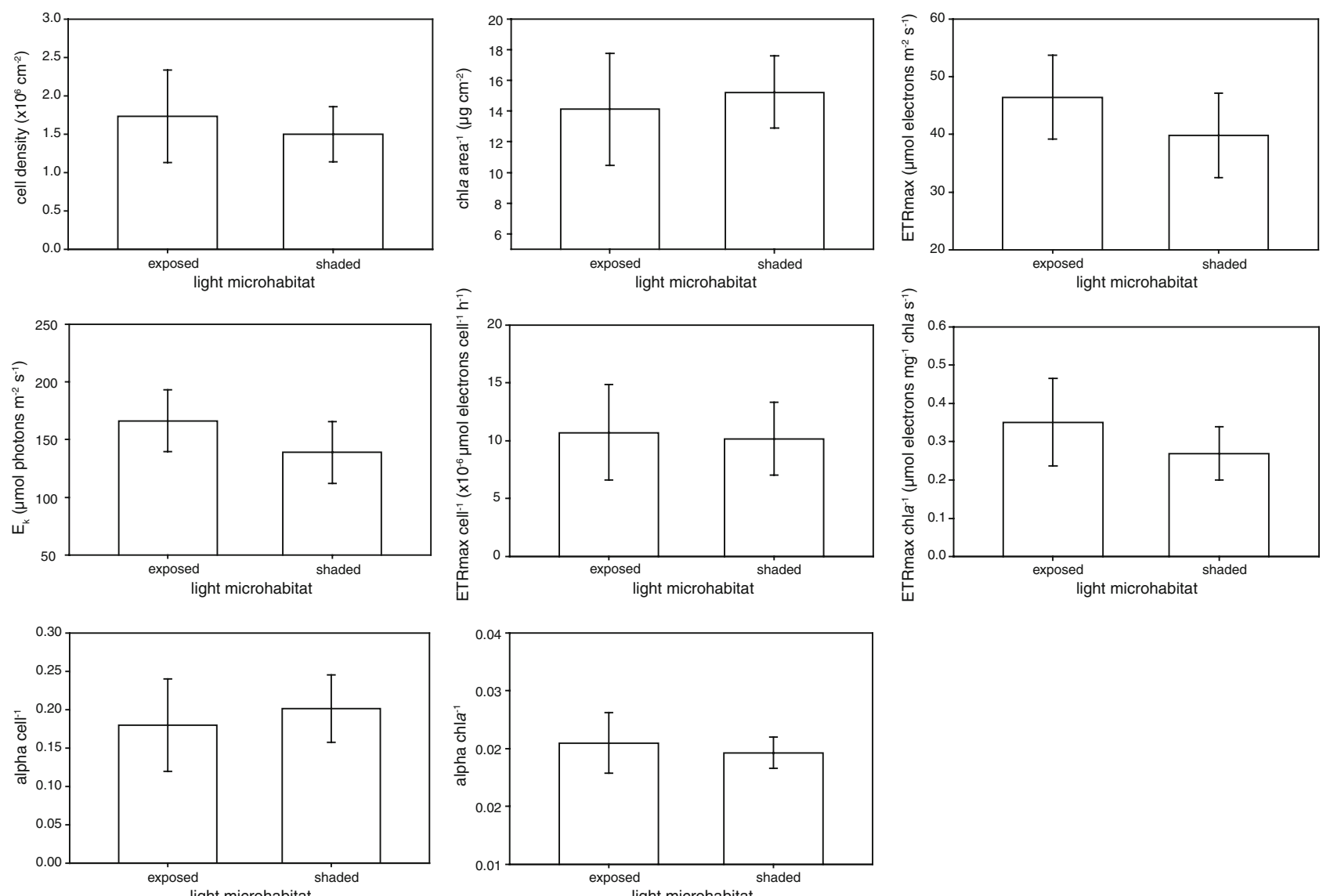

light microhabitat

Fig. 5 Light microhabitat differences (average \pm SD) in Madracis pharensis at $25 \mathrm{~m}$ for the original variables that are highly correlated to (represented in) PC2. Note that statistical significances throughout the text are based on the overall variation of the component representing these variables and not on individual comparisons

and remain relatively stable at the intra-colony level and at the level of microhabitat variation studied: temperature and light spectral irradiance.

A role for colour niches?

The present study shows that symbiont ITS2 diversity in M. pharensis is linked to host colour morph, with the majority of brown colonies hosting type B7, while purple and green ones harbour preferentially type B15. In contrast to the present results, Klueter et al. (2006) reported no symbiont type variation for two fluorescence colour morphs of the coral Montipora digitata. Still, in M. pharensis, the occurrence of a certain symbiont type is not exclusive of a certain host colour, and therefore, symbiont distribution does not appear to represent a case of genetically constrained, strict specificity between symbiont and colour morph. The data in Frade et al. (2008), on brown M. pharensis morphs, also show a strong effect of depth on symbiont diversity, type B7 being replaced by B15. This strongly suggests that both depth and host colour are involved in controlling symbiont diversity. Colour variation at the polyp level (Fig. 2 and 
Vermeij et al. 2002) does not add information to overall coenosarc colour in explaining symbiont distribution.

A most parsimonious hypothesis is that these two factors, depth and host colour morph, represent the same abiotic topology. A curious candidate is temperature, known to decrease with depth along the reef slope (for sampling site see Frade et al. 2008), and reported to be potentially related to host colour at least in shallow water (Fabricius 2006). However, it is not likely that this could be a significant case for the $M$. pharensis colonies at $25-\mathrm{m}$. A better candidate linking depth and host colour morph is light spectral distribution within coral tissue. Light spectrum is known to change dramatically across depth (falling mostly in the blue-green region at $25 \mathrm{~m}$ depth) and be less variable at a microhabitat scale (Frade et al. 2008). Light spectrum will also likely be different within the tissue of the different colour morphs. These morphs may correspond to variation in GFP-like proteins, known to be a source of fluorescence and colour patterns of reef-building corals (Dove et al. 2001). The photoprotective or photoenhancing function of the GFP-like proteins is uncertain (Wiedenmann et al. 2004), but different host tissue colours probably influence the internal light climate available to the endosymbionts (Dove et al. 2006). Not much is known about GFP-like proteins in Madracis species. Vermeij et al. (2002) detected green fluorescence in most Madracis species and their histological examinations revealed that a fluorescent layer is located below the symbiont layer in the coral endoderm (Vermeij et al. 2002), suggesting that this fluorescent layer increases the amount of light that the symbionts receive by wavelength transformation and backscattering (Schlichter et al. 1994). In M. pharensis, green fluorescence was present at a broader emission range (520$570 \mathrm{~nm}$ ) in the green morphs than in the brown morphs, where it was restricted to a single emission peak (at $530 \mathrm{~nm}$ ) (Vermeij et al. 2002). Hypothetically, the increase in blue-green light availability with depth could link the cooccurrence of type B15 as the dominant symbiont in green morphs of $M$. pharensis and at greater depths on the reef. The presence of type B15 Symbiodinium could be related with a higher competence in harvesting green light. The higher amount of peridinin demonstrated for type B15 could be advantageous in more greenish environments, as this pigment would transfer onto chl $a$ the high energy electron states produced by the absorption of the irradiance energy that could potentially be backscattered from the fluorescent layer. Still, if this hypothesis is to be correct, the role of purple morphs remains unclear.

The present case of symbiont distribution in M. pharensis may constitute an example of light quality and quantity niche specification. Symbiont types B7 and B15 would be shallow and deep adapted rather than simply light and shade adapted. Niche diversification theory has been proposed previously for symbiont distribution throughout irradiance levels (Iglesias-Prieto and Trench 1997a; Sampayo et al. 2007). Although it is known that phototrophic organisms utilize specific parts of the light spectrum and this constitutes an important acclimation axis (Falkowski and Laroche 1991), it is unclear whether distinct responses to light quality can play a role in the distribution of Symbiodinium.

\section{Stability of the association}

According to abiotic data (Frade et al. 2008), the transplantations represented a temperature change of about $0.1^{\circ} \mathrm{C}$ and a three-fold difference in irradiance ( 247 and $730 \mu \mathrm{mol}$ photons $\mathrm{m}^{-2} \mathrm{~s}^{-1}$ for 25 and $10 \mathrm{~m}$, respectively). These transplantations lasted for 1 month and produced a high occurrence of bleaching and mortality on the colonies that were moved upwards. This is likely caused by high photooxidative stress (Iglesias-Prieto and Trench 1997b). The bleaching response would probably have been reduced if transplantations would have taken place gradually across depths. The slight tendency for higher survival of brown morphs is interesting as this is the main colour morph existing at 10-m depth. This reflects that there are depth-related abiotic factors shaping the distribution of $M$. pharensis colour morphs. On the other hand, the tendency for higher survival of transplants hosting symbiont type B15 is intriguing as it contradicts the depth distribution of these symbionts. A possible explanation is that although not being adapted to such broad environmental gradients as type B7, type B15 has a higher short-term stress tolerance. This implies that the recent acclimation history of a certain symbiont (B7, in this case) can be more important for stress tolerance than its adaptive potential as a species, when facing abrupt environmental change.

Symbiont diversity in $M$. pharensis is probably determined at an early life stage, hypothetically after larvae settlement, as the (limited) data available for M. pharensis suggest that this species has an open or horizontal symbiont transmission mode (Vermeij et al. 2003), where the developed planulae do not appear to contain algal cells. Madracis pharensis is an example of a species that establishes symbiosis with two physiologically distinct algal genotypes but does not show indications of potential symbiont shuffling under environmental change.

\section{Final considerations}

The ecological distribution of symbiont types in M. pharensis, where symbiont variation across depths and between host colour morphs contrasts with constancy between shaded and exposed microhabitats at fixed depths, suggests that symbiont presence is driven, at least partially, by light spectral 
niches. Total irradiance, per se, cannot explain symbiont variation. The total absence of symbiont shuffling suggests that symbiont diversity is prevalent over time once established, even when environment changes (Iglesias-Prieto et al. 2004; Goulet 2006). This is consistent with the existence of a high level of symbiont specificity and contrasts with interpretations favouring relatively flexible symbioses and symbiont shuffling in scleractinian corals (Berkelmans and van Oppen 2006). The remarkable photophysiological differences between symbiont types within clade $\mathrm{B}$ confirm that the clade classification does not necessarily imply functional identity (LaJeunesse 2001; Tchernov et al. 2004) and supports the use of ITS2 as an ecological and functionally meaningful marker in Symbiodinium. This study constitutes new in situ evidence for the role of Symbiodinium functional diversity in the acclimation and adaptation of corals to the reef environment.

Acknowledgments We thank Drs. Joerg Wiedenmann, Mark Vermeij and Erik Meesters for discussions on specific parts of the manuscript. Gerard Nieuwland and the staff in CARMABI provided great logistic support. We are obliged to Jeandra de Palm and Dr. Osric Wanga from the Analytisch Diagnostisch Centrum (ADC) in Curaçao for the use of their freeze-drier. Berber van Beek gently performed all cell size determinations. We are grateful to Dr. Marcel Veldhuis, who provided the flowcytometer for cell density analyses. Research was funded by FCTPortugal through a PhD grant (SFRH/BD/13382/2003) to the first author. The manuscript benefited from the remarks of two anonymous reviewers.

Open Access This article is distributed under the terms of the Creative Commons Attribution Noncommercial License which permits any noncommercial use, distribution, and reproduction in any medium, provided the original author(s) and source are credited.

\section{References}

Apprill AM, Gates RD (2007) Recognizing diversity in coral symbiotic dinoflagellate communities. Mol Ecol 16:1127-1134

Bak RPM (1977) Coral reefs and their zonation in the Netherlands Antilles. Am Assoc Pet Geol Bull 4:3-16

Beer S, Ilan M, Eshel A, Weil A, Brickner I (1998) Use of pulse amplitude modulated (PAM) fluorometry for in situ measurements of photosynthesis in two Red Sea faviid corals. Mar Biol 131:607-612

Berkelmans R, van Oppen MJH (2006) The role of zooxanthellae in the thermal tolerance of corals: a 'nugget of hope' for coral reefs in an era of climate change. Proc R Soc Lond, B 273:2305-2312

Brown BE, Downs CA, Dunne RP, Gibb SW (2002) Preliminary evidence for tissue retraction as a factor in photoprotection of corals incapable of xanthophyll cycling. J Exp Mar Biol Ecol 277:129-144

Coffroth MA, Santos SR (2005) Genetic diversity of symbiotic dinoflagellates in the genus Symbiodinium. Protist 156:19-34

Diekmann OE, Bak RPM, Tonk L, Stam WT, Olsen JL (2002) No habitat correlation of zooxanthellae in the coral genus Madracis on a Curacao reef. Mar Ecol Prog Ser 227:221-232

Dove SG, Hoegh-Guldberg O, Ranganathan S (2001) Major colour patterns of reef-building corals are due to a family of GFP-like proteins. Coral Reefs 19:197-204

Dove S, Ortiz JC, Enriquez S, Fine M, Fisher P, Iglesias-Prieto R, Thornhill D, Hoegh-Guldberg O (2006) Response of holosymbi- ont pigments from the scleractinian coral Montipora monasteriata to short-term heat stress. Limnol Oceanogr 51:1149-1158

Enriquez S, Mendez ER, Iglesias-Prieto R (2005) Multiple scattering on coral skeletons enhances light absorption by symbiotic algae. Limnol Oceanogr 50:1025-1032

Fabricius KE (2006) Effects of irradiance, flow, and colony pigmentation on the temperature microenvironment around corals: Implications for coral bleaching? Limnol Oceanogr 51:30-37

Falkowski PG, Laroche J (1991) Acclimation to spectral irradiance in algae. J Phycol 27:8-14

Frade PR, de Jongh F, Vermeulen F, van Bleijswijk J, Bak RP (2008) Variation in symbiont distribution between closely related coral species over large depth ranges. Mol Ecol 17:691-703

Frade PR, Bongaerts P, Winkelhagen AJS, Tonk L, Bak RPM (in press) In situ photobiology of corals over large depth ranges: a multivariate analysis on the roles of environment, host, and algal symbiont. Limnol Oceanogr

Gorbunov MY, Kolber ZS, Lesser MP, Falkowski PG (2001) Photosynthesis and photoprotection in symbiotic corals. Limnol Oceanogr 46:75-85

Goulet TL (2006) Most corals may not change their symbionts. Mar Ecol Prog Ser 321:1-7

Hoegh-Guldberg O, Mumby PJ, Hooten AJ, Steneck RS, Greenfield P, Gomez E, Harvell CD, Sale PF, Edwards AJ, Caldeira K, Knowlton N, Eakin CM, Iglesias-Prieto R, Muthiga N, Bradbury RH, Dubi A, Hatziolos ME (2007) Coral reefs under rapid climate change and ocean acidification. Science 318:1737-1742

Iglesias-Prieto R, Trench RK (1994) Acclimation and adaptation to irradiance in symbiotic dinoflagellates. 1. Responses of the photosynthetic unit to changes in photon flux-density. Mar Ecol Prog Ser 113:163-175

Iglesias-Prieto R, Trench RK (1997a) Photoadaptation, photoacclimation and niche diversification in invertebrate-dinoflagellate symbioses. Proc 8th Int Coral Reefs Symp 2:1319-1324

Iglesias-Prieto R, Trench RK (1997b) Acclimation and adaptation to irradiance in symbiotic dinoflagellates. II. Response of chlorophyll-protein complexes to different photon-flux densities. Mar Biol 130:23-33

Iglesias-Prieto R, Beltran VH, LaJeunesse TC, Reyes-Bonilla H, Thome PE (2004) Different algal symbionts explain the vertical distribution of dominant reef corals in the eastern Pacific. Proc R Soc Lond, B 271:1757-1763

Jones RJ, Yellowlees D (1997) Regulation and control of intracellular algae (equals zooxanthellae) in hard corals. Philos Trans R Soc Lond B 352:457-468

Klueter A, Loh W, Hoegh-Guldberg O, Dove S (2006) Physiological and genetic properties of two fluorescent colour morphs of the coral Montipora digitata. Symbiosis 42:123-134

LaJeunesse TC (2001) Investigating the biodiversity, ecology, and phylogeny of endosymbiotic dinoflagellates in the genus Symbiodinium using the its region: In search of a "species" level marker. J Phycol 37:866-880

LaJeunesse TC (2002) Diversity and community structure of symbiotic dinoflagellates from Caribbean coral reefs. Mar Biol 141:387-400

LaJeunesse TC, Lambert G, Andersen RA, Coffroth MA, Galbraith DW (2005) Symbiodinium (Pyrrhophyta) genome sizes (DNA content) are smallest among dinoflagellates. J Phycol 41:880-886

LaJeunesse TC, Loh WKW, van Woesik R, Hoegh-Guldberg O, Schmidt GW, Fitt WK (2003) Low symbiont diversity in southern Great Barrier Reef corals, relative to those of the Caribbean. Limnol Oceanogr 48:2046-2054

Loram JE, Trapido-Rosenthal HG, Douglas AE (2007) Functional significance of genetically different symbiotic algae Symbiodinium in a coral reef symbiosis. Mol Ecol 16:4849-4857

Marsh JA (1970) Primary productivity of reef-building calcareous red algae. Ecology 51:255-263 
Muller P, Li XP, Niyogi KK (2001) Non-photochemical quenching. A response to excess light energy. Plant Physiol 125:1558-1566

Oswald F, Schmitt F, Leutenegger A, Ivanchenko S, D'Angelo C, Salih A, Maslakova S, Bulina M, Schirmbeck R, Nienhaus GU, Matz MV, Wiedenmann J (2007) Contributions of host and symbiont pigments to the coloration of reef corals. Febs Journal 274:1102-1109

Porter JW, Muscatine L, Dubinsky Z, Falkowski PG (1984) Primary production and photoadaptation in light-adapted and shade-adapted colonies of the symbiotic coral, Stylophora pistillata. Proc R Soc Lond, B 222:161-180

Robison JD, Warner ME (2006) Differential impacts of photoacclimation and thermal stress on the photobiology of four different phylotypes of Symbiodinium (Pyrrhophyta). J Phycol 42:568-579

Rowan R, Powers DA (1991) A molecular genetic classification of zooxanthellae and the evolution of animal-algal symbioses. Science 251:1348-1351

Salih A, Larkum A, Cox G, Kuhl M, Hoegh-Guldberg O (2000) Fluorescent pigments in corals are photoprotective. Nature 408:850-853

Sampayo EM, Franceschinis L, Hoegh-Guldberg O, Dove S (2007) Niche partitioning of closely related symbiotic dinoflagellates. Mol Ecol 16:3721-3733

Schlichter D, Meier U, Fricke HW (1994) Improvement of photosynthesis in zooxanthellate corals by autofluorescent chromatophores. Oecologia 99:124-131

Sheppard CRC, Knowlton N, Lang J, Fenner D, Weil E, Zea S, Bak RPM, Sanchez AS, Turak E (2007) Coralpedia, a guide to Caribbean corals, octocorals and sponges. CD ROM issued by OTEP, FCO, UK

Tchernov D, Gorbunov MY, de Vargas C, Yadav SN, Milligan AJ, Haggblom M, Falkowski PG (2004) Membrane lipids of symbiotic algae are diagnostic of sensitivity to thermal bleaching in corals. Proc Natl Acad Sci USA 101:13531-13535

Thornhill DJ, Lajeunesse TC, Santos SR (2007) Measuring rDNA diversity in eukaryotic microbial systems: how intragenomic variation, pseudogenes, and PCR artifacts confound biodiversity estimates. Mol Ecol 16:5326-5340

Titlyanov EA (1981) Adaptation of reef-building corals to low light intensity. Proc 4th Int Coral Reef Symp 2:39-43

Trench RK (1993) Microalgal-invertebrate symbioses - a review. Endocytobiosis and Cell Research 9:135-175 van Oppen MJH, Palstra FP, Piquet AMT, Miller DJ (2001) Patterns of coral-dinoflagellate associations in Acropora: significance of local availability and physiology of Symbiodinium strains and host-symbiont selectivity. Proc R Soc Lond, B 268:1759-1767

Vermeij MJA, Bak RPM (2002) How are coral populations structured by light? Marine light regimes and the distribution of Madracis. Mar Ecol Prog Ser 233:105-116

Vermeij MJA, Bak RPM (2003) Species-specific population structure of closely related coral morphospecies along a depth gradient (5-60 m) over a Caribbean reef slope. Bull Mar Sci 73:725-744

Vermeij MJA, Delvoye L, Nieuwland G, Bak RPM (2002) Patterns in fluorescence over a Caribbean reef slope: the coral genus Madracis. Photosynthetica 40:423-429

Vermeij MJA, Sampayo E, Broker K, Bak RPM (2003) Variation in planulae release of closely related coral species. Mar Ecol Prog Ser 247:75-84

Vermeij MJA, Frade PR, Jacinto RIR, Debrot AO, Bak RPM (2007) Habitat-related differences in population structure are associated with coral reproductive mode: a comparison between fringing reef and inland bay coral communities. Mar Ecol Prog Ser 351:91-102

Veron JEN (2000) Corals of the world. Australian Institute of Marine Science, Townsville

Warner ME, Berry-Lowe S (2006) Differential xanthophyll cycling and photochemical activity in symbiotic dinoflagellates in multiple locations of three species of Caribbean coral. J Exp Mar Biol Ecol 339:86-95

Warner ME, LaJeunesse TC, Robison JD, Thur RM (2006) The ecological distribution and comparative photobiology of symbiotic dinoflagellates from reef corals in Belize: Potential implications for coral bleaching. Limnol Oceanogr 51:1887-1897

Wells JW (1973) New and old scleractinian corals from Jamaica. Bull Mar Sci 23:16-55

Wiedenmann J, Ivanchenko S, Oswald F, Nienhaus GU (2004) Identification of GFP-like proteins in nonbioluminescent, azooxanthellate anthozoa opens new perspectives for bioprospecting. Mar Biotechnol 6:270-277

Zuur AF, Ieno EN, Smith GM (2007) Analysing ecological data. Springer, New York 